\title{
How Changes in Job Resources and Personal Resources Predict Employee Engagement
}

\author{
T. J. R. Thisera, G. A. D. S. Wijesundara \\ Department of Human Resource Management, Faculty of Commerce and Management Studies, University of Kelaniya, Kelaniya, \\ Sri Lanka \\ Email: jeewanthi@kln.ac.lk
}

How to cite this paper: Thisera, T. J. R., \& Wijesundara, G. A. D. S. (2020). How Changes in Job Resources and Personal Resources Predict Employee Engagement. Open Journal of Business and Management, 8, 2623-2632. https://doi.org/10.4236/ojbm.2020.86162

Received: August 15, 2020

Accepted: November 17, 2020

Published: November 20, 2020

Copyright (c) 2020 by author(s) and Scientific Research Publishing Inc. This work is licensed under the Creative Commons Attribution International License (CC BY 4.0).

http://creativecommons.org/licenses/by/4.0/

\begin{abstract}
This study examines how job resources (i.e., job autonomy, supervisor support, and reward and recognition) and personal resources (i.e., self-efficacy and optimism) affect employee engagement with special reference to managerial employees apparel manufacturing industry in Sri Lanka. This explanatory study is positivistic and deductive, which adopted the survey strategy. The present study uses the mono method in data collection and analysis. A standard questionnaire was used to collect data, and analysis was done using SPSS. The hypothesized model of the study was tested using simple linear regression. Results revealed a positive impact of job resources and personal resources on employee engagement. This study contributes to the existing knowledge while providing many managerial implications.
\end{abstract}

\section{Keywords}

Employee Engagement, Job Resources, Personal Resources

\section{Introduction}

Work engagement, which refers to a positive, affective-motivational state of high energy combined with high levels of dedication and a strong focus on work (Schaufeli \& Bakker, 2010), is alluring concepts among practitioners and academicians (Kassa \& Ranju, 2015). Work engagement becomes a more popular concept since it favorably affects employee, team, and organizational outcomes (Bakker \& Albrecht, 2018). Further, work engagement helps organizations flourish or stand firm against the rapidly changing economic times (Sorenson, 2013). The engagement has become a fascinating topic among policymakers and employers as a new mechanism of improving higher performance (Bailey, Madden, Alfes, \& Fletcher, 2017). Further, employee engagement affects employee 
attitudes, absenteeism, turnover, individual, group and organizational performance, quality of customer experience, and customer loyalty. Maynard (2016) mentioned that an engaged employee is productive by two times than a disengaged employee, and that will ensure a better service for customers while leading the organization towards more profits. Even though work engagement has many positive consequences, there is an engagement crisis all over the world.

Gallup studies (http://www.gallup.com/, 2013) have shown that only 13\% of employees are engaged in their job, while $63 \%$ of employees are not engaged. The remaining is actively disengaged. In the United States, only 34\% of employees are engaged (http://www.gallup.com/, 2018). Further, the estimated cost of the lost productivity of actively disengaged employees is USD 483 billion to 605 billion (http://www.gallup.com/, 2017). In Sri Lanka, 14\% of employees are engaged, and $62 \%$ of the workforce is not engaged. It showed that $23 \%$ of employees were actively disengaged (Crabtree, 2013). With this evidence, few discussions on employee engagement were conducted with managerial personnel attached to the apparel industry in Sri Lanka. These discussions revealed that many employees are not engaged fully in their jobs. Besides, a pilot survey was conducted using managerial level employees. Its findings show that $11 \%$ of employees are highly disengaged, and $66 \%$ of employees are moderately engaged. Only $23 \%$ of employees are highly engaged. Accordingly, the majority of employees are not fully engaged in their job. Hence, this study examines why managerial employees are not engaged in their jobs with special reference to the apparel sector in Sri Lanka?

\section{Literature Review and Hypotheses Development}

One of the common definitions for work engagement is a positive, fulfilling, work-related state of mind that is characterized by vigor, dedication, and absorption (Schaufeli, Salanova, Gonzalez-Roma, \& Bakker, 2002). As stated, there are many positive consequences of engagement towards individuals, groups, and organizations. For example, engagement increases the innovative work behavior of employees (De Spiegelaere, Van Gyes, De Witte, Niesen, \& Van Hootegem, 2014), better job performance (Bakker \& Demerouti, 2007), organizational commitment (Geldenhuys, Laba, \& Venter, 2014). Different researchers have identified many factors that affect employee engagement. For example, Saks (2006) showed job characteristics, perceived organizational and supervisory support, reward and recognition, procedural and distributive justice as influential factors over engagement. Moreover, training and development practices (Thavakumar \& Nawaratne, 2015), transformational leadership (Thisera \& Sewwandi, 2018), career development and work content are some other antecedents of employee engagement. Moreover, some researchers (e.g., Carter, Nesbit, Badham, Parker, \& Sung, 2018; Kotze, 2018) examined how job and personal resources affect work engagement. Especially, Demerouti, Bakker, De Jonge, Janssen, and Schaufeli (2001) introduced the JD-R model for identifying differ- 
ent job characteristics as influential factors in explaining various aspects of employee work lives (e.g., job strain, burnout, and engagement). This model categorized job demands and resources as the main working conditions of a job while emphasizing the underlying assumption indicating that job resources are positively related to work engagement (Bakker \& Demerouti, 2007). Accordingly, job resources may include social support, growth opportunities, organizational support, job security, and opportunity for advancement (Coetzee \& De Villiers, 2010). The JD-R model suggested that personal resources have an equal motivational impact on work engagement (Xanthopoulou, Bakker, Demerouti, \& Schaufeli, 2007).

\section{Job Resources and Employee Engagement}

Many empirical studies (e.g., Bakker, Hakanen, Demerouti, \& Xanthopoulou 2007; Salanova \& Schaufeli, 2008; Hakanen, Schaufeli, \& Ahola, 2008) have shown that job resources impact positively on engagement. Schaufeli and Bakker (2004) described that when employees feel that their jobs are less resourceful, they will leave the organization. If the company provides adequate job resources for their employees, they will remain with the organization. Thus, a lack of job resources increases the disengagement level of employees. Based on this evidence, the first hypothesis is proposed as;

$\mathrm{H} 1$ : There is a positive impact on job resources on work engagement.

This study focuses on three main job resources (i.e., job autonomy, perceived supervisor support, and reward and recognition), which are critical for employees attached to the apparel sector. Job autonomy is the degree of employee sovereignty in making job-related decisions (Hackman \& Oldman, 1975). Further, researchers (e.g., De Lange, De Witte, \& Notelaers, 2008; Bakker \& Demerouti, 2007; Demerouti \& Bakker, 2008; Saks, 2006) have shown that job autonomy positively influences the engagement. Therefore, the second hypothesis is set as:

$\mathrm{H} 1_{\mathrm{a}}$ : There is a positive impact of job autonomy on work engagement.

Thirdly, supervisory support, which is defined as the degree of employee perception towards their supervisor's enthusiasm for his employees' well-being and the contribution that the supervisor makes (Tuzun \& Devrani, 2011) is considered. If the supervisor supports his subordinates to carry out their work effectively, employees will work hard to achieve organizational goals. Further, supervisory support is positively related to work engagement (e.g., Demerouti \& Bakker, 2008; Saks, 2006; Xanthopoulou et al., 2007). Based on this empirical evidence, the following hypothesis is suggested.

$\mathrm{H}_{\mathrm{b}}$ : There is a positive impact of supervisory support on work engagement.

When looking at the reward and recognition, researchers (e.g., Kahn, 1990) have described that reward and recognition positively impact on work engagement. Hence, the following hypothesis is set.

$\mathrm{H} 1_{c}$ : There is a positive impact of reward and recognition on work engagement. 
Xanthopoulou, Bakker, Demerouti, \& Schufeli (2009) mentioned that personal resources (e.g., self-efficacy, optimism, and organization-based self-esteem) affect the work engagement, next to job resources. Supporting this argument, Prieto, Soria, Martínez, \& Schaufeli (2008) found that personal resources control the level of burnout while increasing the level of engagement. Similarly, empirical studies (e.g., Hu, Schaufeli, \& Taris, 2011; Xanthopoulou et al., 2007; Xanthopoulou, Bakker, Demerouti, \& Schufeli, 2009) have shown that personal resources (e.g., self-efficacy, optimism, organization-based self-esteem) positively impact on work engagement. Accordingly, the following three hypotheses are proposed.

$\mathrm{H} 2$ : There is a positive impact of personal resources on work engagement

$\mathrm{H} 2_{\mathrm{a}}$ : There is a positive impact of self-efficacy on work engagement

$\mathrm{H} 2_{\mathrm{b}}$ : There is a positive impact of optimism on work engagement

Figure 1 shows the conceptual framework of the study.

\section{Research Methodology}

The present study is positivistic and deductive research. The purpose of the present study is explanatory, and it explains the causality between job and personal resources and employee engagement. Accordingly, it adopts the survey strategy and follows the mono method. Moreover, this cross-sectional study uses managerial employees attached to the apparel sector in Sri Lanka. As the pilot survey results reveal, executives in the apparel sector show disengaged behaviors at work. Further, the apparel sector is one of the key players in the Sri Lankan economy. Therefore, this sector was chosen for the study purpose. Data collection was done via a self-administered questionnaire included three main parts for demographic information (i.e., age, gender, marital status, highest educational qualifications, and tenure), job resources (job autonomy, supervisor support, reward, and recognition) and personal resources (self-efficacy and optimism). The questionnaire was distributed among 230 managerial level employees, and 174 questionnaires were returned. 167 questionnaires were used for the final analysis after excluding incomplete responses.

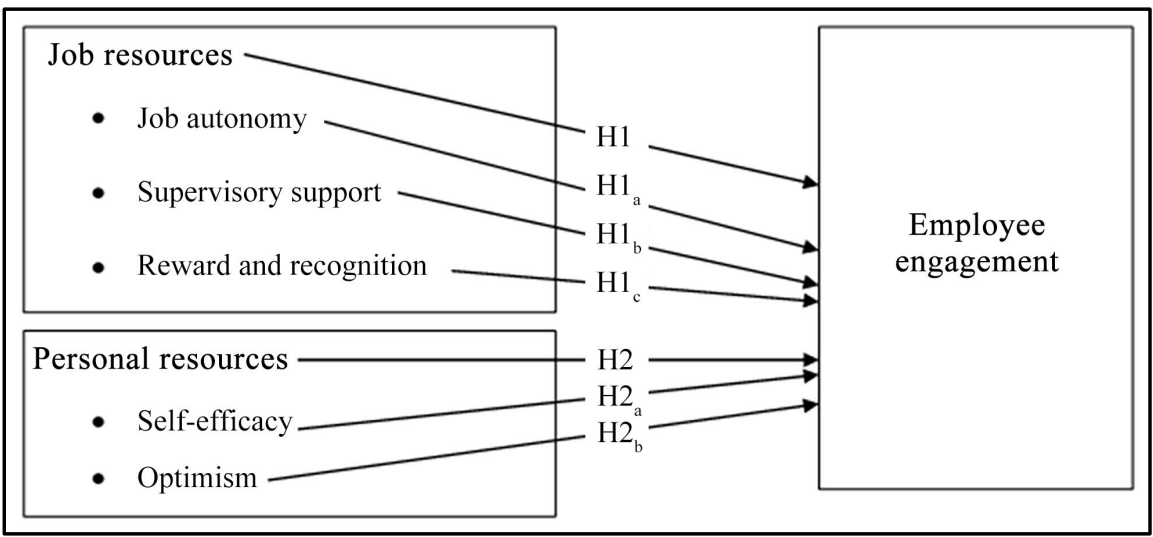

Figure 1. Conceptual framework of the study. 


\section{Measures}

Employee engagement was measured via Utrecht Work Engagement Scale (UWES) developed by Schaufeli, Bakker and Salanova (2006). It consists of seventeen (17) items for measuring three dimensions of engagement (i.e., vigor, absorption, and dedication). This 7-point Likert scale has anchors ranging from never (0) to always (6). Job-Demand Resource questionnaire (Bakker, Demerouti, \& Verbeke, 2004) was used to measure job resources and personal resources. All the items were 5 points Likert scale (Never to very often).

\section{Data Analysis}

\section{Sample Composition}

The sample consisted of a majority (59\%) of males and $41 \%$ females. The majority of respondents (39\%) were in the age group of between 35 - 45 years. $64 \%$ of the sample had qualified with a bachelor's degree. $20 \%$ of respondents have a postgraduate degree. Others have passed the advanced level examination.

\section{Hypotheses Testing}

Preliminary analysis (i.e., normality, linearity, homoscedasticity, reliability, validity, multicollinearity, common method variance) was conducted before testing hypotheses. Moreover, simple linear regression was used to test the hypotheses of the study.

As shown in Model 1 (Refer Table 1), R-value is .71 and $\mathrm{R}^{2} .51$. It denotes that aggregate job resources explain the variance of employee engagement by $51 \%$. The p-value is .00, which is less than .05. The Beta value .71, and it is positive. Accordingly, $\mathrm{H} 1$ is supported. Hence, it can be concluded that job resources positively affect employee engagement. Job autonomy also positively impacts on employee engagement. The beta value is .73 , and the p-value is .00 . Therefore, $\mathrm{H} 1_{\mathrm{a}}$ is supported. Job autonomy explains $32 \%\left(\mathrm{R}^{2}=.32\right)$ of variance in employee engagement. Model 3 shows that supervisor support positively affects employee engagement. The beta value is .80 . R-value is .65 and $\mathrm{R}^{2}$ is .43 . $\mathrm{P}$-value is .00 . Therefore, $\mathrm{H} 1_{\mathrm{b}}$ is supported. When looking at the reward and recognition, it shows a positive beta value of .88 . P-value is .00 and $\mathrm{R}^{2}$ is $.38 .38 \%$ of the variance of the dependent variable is explained by reward and recognition. Hence, $\mathrm{H} 1_{\mathrm{c}}$ is accepted.

Table 2 depicts the statistics of regression analysis for personal resources and employee engagement. Model 5 (Refer Table 2) shows a positive beta value of 1.01. P-value is .00. Moreover, $\mathrm{R}^{2}$ is .34. It means that personal resources explain the variance of employee engagement by $34 \%$. Therefore, $\mathrm{H} 2$ is accepted. Model 6 regressed employee engagement by self-efficacy. Beta is .89 and p-value is .00 . Accordingly, $\mathrm{H} 2_{\mathrm{a}}$ is accepted. $\mathrm{H} 2_{\mathrm{b}}$ is also statistically supported. P-value is .00 , beta value is .89 . $R^{2}$ is .29 , which explained $29 \%$ of the variance of employee engagement. Accordingly, self-efficacy positively influences employee engagement. When considering optimism as a personal resource, results show a beta value 
Table 1. Job resources and employee engagement.

\begin{tabular}{ccccc}
\hline Regression & Model 1: EE <- JR Model 2: $\mathrm{EE}<-\mathrm{JA}$ & Model 3: $\mathrm{EE}<-\mathrm{SS}$ Model 4: $\mathrm{EE}<-\mathrm{RR}$ \\
\hline $\begin{array}{c}\text { Independent } \\
\text { variable }\end{array}$ & $\mathrm{JR}$ & $\mathrm{JA}$ & $\mathrm{SS}$ & $\mathrm{RR}$ \\
Beta & .71 & .73 & .80 & .88 \\
$\mathrm{~B}$ & 1.09 & .56 & .11 & .62 \\
P-value & .00 & .00 & .00 & .00 \\
& & Model Summary & & .62 \\
$\mathrm{R}$ & .71 & .56 & .65 & .38 \\
$\mathrm{R}^{2}$ & .51 & .32 & .43 & .37 \\
Adjusted $\mathrm{R}^{2}$ & .50 & .31 & .42 & \\
\hline
\end{tabular}

Note: EE-Employee engagement, JR-Job resources, JA-Job autonomy, SS-Supervisor Support, $R R-$ Reward and recognition.

Table 2. Personal resources and employee engagement.

\begin{tabular}{cccc}
\hline Regression & Model 5: EE <- PR & Model 6: EE <- SE & Model 7: EE <- OP \\
\hline Independent variable & PR & SE & OP \\
Beta & 1.01 & .89 & .66 \\
B & .58 & .54 & .48 \\
P-value & .01 & .00 & .00 \\
& Model Summary & & .48 \\
$\mathrm{R}$ & .58 & .54 & .23 \\
$\mathrm{R}^{2}$ & .34 & .29 & .22 \\
Adjusted $\mathrm{R}^{2}$ & .33 & .28 &
\end{tabular}

Note: EE-Employee engagement, $P R$-Personal resources, SE-Self-efficacy, OP--Optimism.

of .66, and the p-value is .00. Hence, $\mathrm{H}_{2}$ is accepted. Further, $23 \%\left(\mathrm{R}^{2}=.23\right)$ of the variance of employee engagement is explained by the optimism of a person.

\section{Discussion}

This study focused on the impact of job resources (i.e., job autonomy, supervisor support, reward, and recognition) and personal resources (i.e., self-efficacy, optimism) on employee engagement. The findings of the study revealed that job resources and personal resources positively affect the engagement of employees. These findings are consistent with previous studies (e.g., Hakanen et al., 2008; Salanova \& Shaufeli, 2008). Further, aligning with previous studies (e.g., De Lange, De Witte, \& Notelaers, 2008; De Spiegelaere et al., 2014), it further revealed a positive impact of job autonomy on work engagement (Beta $=.73, p$ $<.00)$. It also showed that supervisor support positively affects employee engagement. As shown by many researchers (e.g., Kahn, 1990; Saks, 2006), reward and recognition has a positive impact (Beta $=.66, \mathrm{p}$-value $=.00, \mathrm{R}^{2}=.38$ ) on en- 
gagement. When looking at personal resources, the study revealed a positive impact of personal resources on engagement. These findings are consistent with previous studies (e.g., Bakker \& Woerkom, 2017). Further, supporting previous findings (e.g., Mache et al., 2014; Hu et al., 2011), the present study found that employee engagement is positively affected by self-efficacy and optimism of a person.

\section{Implications}

There are limited research studies on employee engagement (e.g., Thisera \& Seewandi, 2018; Wickramasinghe \& Perera, 2014) and job characteristics (Thisera \& Nawaratne, 2018) in Sri Lanka. Iddagoda, Opatha and Gunawardana (2016) described that there is an empirical gap regarding work engagement and personal resources in Sri Lanka. Therefore, this study nurtures the existing literature while fulfilling the knowledge gap. Further, the findings provide many insights for managerial employees, decision-makers, and policymakers in organizations. Based on the results, managers can enhance job resources (e.g., job autonomy, supervisor support, reward, and recognition) to improve the engagement level of managerial employees. Notably, it is necessary to take actions for enhancing job autonomy and creating favorable interpersonal relations. Further, an attractive reward and recognition plans should be used. When looking at personal resources, managers should focus on improving self-efficacy and optimism within employees via different training and counseling programs.

\section{Limitations of the Study}

The present study is cross-sectional and used only a single method of data collection and analysis. Furthermore, it considered only executive and above level employees attached to the apparel industry in Sri Lanka. Selected job resources and personal resources were used for the study purpose. Therefore, it is recommended to take the necessary actions to overcome these limitations in future research.

\section{Conflicts of Interest}

The authors declare no conflicts of interest regarding the publication of this paper.

\section{References}

Bailey, C., Madden, A., Alfes, K., \& Fletcher, L. (2017). The Meaning, Antecedents and Outcomes of Employee Engagement: A Narrative Synthesis. International Journal of Management Reviews, 19, 31-53. https://doi.org/10.1111/ijmr.12077

Bakker, A. B., \& Albrecht, S. (2018). Work Engagement: Current Trends. Career Development International, 23, 4-11. https://doi.org/10.1108/CDI-11-2017-0207

Bakker, A. B., \& Demerouti, E. (2007). The Job Demands-Resources Model: State of the Art. Journal of Managerial Psychology, 22, 309-328. 
https://doi.org/10.1108/02683940710733115

Bakker, A. B., \& van Woerkom, M. (2017). Flow at Work: A Self-Determination Perspective. Occupational Health Science, 1, 47-65. https://doi.org/10.1007/s41542-017-0003-3

Bakker, A. B., Demerouti, E., \& Verbeke, W. (2004). Using the Job Demands-Resources Model to Predict Burnout and Performance. Human Resource Management, 43, 83-104. https://doi.org/10.1002/hrm.20004

Bakker, A. B., Hakanen, J. J., Demerouti, E., \& Xanthopoulou, D. (2007). Job Resources Boost Work Engagement, Particularly When Job Demands Are High. Journal of Educational Psychology, 99, 274-284. https://doi.org/10.1037/0022-0663.99.2.274

Carter, W. R., Nesbit, P. L., Badham, R. J., Parker, S. K., \& Sung, L. K. (2018). The Effects of Employee Engagement and Self-Efficacy on Job Performance: A Longitudinal Field Study. The International Journal of Human Resource Management, 29, 2483-2502. https://doi.org/10.1080/09585192.2016.1244096

Coetzee, M., \& De Villiers, M. (2010). Sources of Job Stress, Work Engagement and Career Orientations of Employees in a South African Financial Institution. Southern African Business Review, 14, 27-58.

Crabtree, S. (2013). Worldwide, 13\% of Employees Are Engaged at Work. Gallup, last modified October, 8. http://www.gallup.com

De Lange, A. H., De Witte, H., \& Notelaers, G. (2008). Should I Stay or Should I Go? Examining Longitudinal Relations among Job Resources and Work Engagement for Stayers versus Movers. Work \& Stress, 22, 201-223. https://doi.org/10.1080/02678370802390132

De Spiegelaere, S., Van Gyes, G., De Witte, H., Niesen, W., \& Van Hootegem, G. (2014). On the Relation of Job Insecurity, Job Autonomy, Innovative Work Behaviour and the Mediating Effect of Work Engagement. Creativity and Innovation Management, 23, 318-330. https://doi.org/10.1111/caim.12079

Demerouti, E., \& Bakker, A. B. (2008). The Oldenburg Burnout Inventory: A Good Alternative to Measure Burnout and Engagement. In Handbook of Stress and Burnout in Health Care (pp. 65-78). http://www.psicopolis.com/burnout/bumesur.pdf

Demerouti, E., Bakker, A. B., De Jonge, J., Janssen, P. P., \& Schaufeli, W. B. (2001). Burnout and Engagement at Work as a Function of Demands and Control. Scandinavian Journal of Work, Environment \& Health, 27, 279-286. https://doi.org/10.5271/sjweh.615

Geldenhuys, M., Laba, K., \& Venter, C. M. (2014). Meaningful Work, Work Engagement, and Organizational Commitment. SA Journal of Industrial Psychology, 40, 1-10. https://doi.org/10.4102/sajip.v40i1.1098

Hackman, R. J., \& Oldman, G. R. (1975). General Job Satisfaction. Work Redesign. Reading, MA: Addison-Wesley.

Hakanen, J. J., Schaufeli, W. B., \& Ahola, K. (2008). The Job Demands-Resources Model: A Three-Year Cross-Lagged Study of Burnout, Depression, Commitment, and Work Engagement. Work \& Stress, 22, 224-241. https://doi.org/10.1080/02678370802379432

Hu, Q., Schaufeli, W. B., \& Taris, T. W. (2011). The Job Demands-Resources Model: An Analysis of Additive and Joint Effects of Demands and Resources. Journal of Vocational Behavior, 79, 181-190. https://doi.org/10.1016/j.jvb.2010.12.009

Iddagoda, A., Opatha, H. H. P., \& Gunawardana, K. (2016). Towards a Conceptualization and an Operationalization of the Construct of Employee Engagement. International Business Research, 9. https://doi.org/10.5539/ibr.v9n2p85

Kahn, W. A. (1990). Psychological Conditions of Personal Engagement and Disengage- 
ment at Work. Academy of Management Journal, 33, 692-724.

https://doi.org/10.5465/256287

Kassa, A. G., \& Raju, R. S. (2015). Investigating the Relationship between Corporate Entrepreneurship and Employee Engagement. Journal of Entrepreneurship in Emerging Economies, 7, 148-167. https://doi.org/10.1108/JEEE-12-2014-0046

Kotze, M. (2018). How Job Resources and Personal Resources Influence Work Engagement and Burnout. African Journal of Economic and Management Studies, 9, 148-164. https://doi.org/10.1108/AJEMS-05-2017-0096

Mache, S., Vitzthum, K., Wanke, E., David, A., Klapp, B. F., \& Danzer, G. (2014). Exploring the Impact of Resilience, Self-Efficacy, Optimism and Organizational Resources on Work Engagement. Work, 47, 491-500.

Maynard, D. (2016). Why Employee Engagement Is a Competitive Advantage.

Prieto, L. L., Soria, M. S., Martínez, I. M., \& Schaufeli, W. (2008). Extension of the Job Demands-Resources Model in the Prediction of Burnout and Engagement among Teachers over Time. Psicothema, 20, 354-360.

Saks, A. M. (2006). Antecedents and Consequences of Employee Engagement. Journal of Managerial Psychology, 21, 600-619. https://doi.org/10.1108/02683940610690169

Salanova, M., \& Schaufeli, W. B. (2008). A Cross-National Study of Work Engagement as a Mediator between Job Resources and Proactive Behaviour. The International Journal of Human Resource Management, 19, 116-131. https://doi.org/10.1080/09585190701763982

Schaufeli, W. B., \& Bakker, A. B. (2004). Job Demands, Job Resources, and Their Relationship with Burnout and Engagement: A Multi-Sample Study. Journal of Organizational Behavior, 25, 293-315. https://doi.org/10.1002/job.248

Schaufeli, W. B., Bakker, A. B., \& Salanova, M. (2006). The Measurement of Work Engagement with a Short Questionnaire: A Cross-National Study. Educational and Psychological Measurement, 66, 701-716. https://doi.org/10.1177/0013164405282471

Schaufeli, W. B., Salanova, M., González-Romá, V., \& Bakker, A. B. (2002). The Measurement of Engagement and Burnout: A Two Sample Confirmatory Factor Analytic Approach. Journal of Happiness Studies, 3, 71-92. https://doi.org/10.1023/A:1015630930326

Schaufeli, W. B., \& Bakker, A. B. (2010). Defining and Measuring Work Engagement: Bringing Clarity to the Concept. In A. B. Bakker, \& M. P. Leiter (Eds.), Work Engagement: A Handbook of Essential Theory and Research (pp. 10-24). New York: Psychology Press.

Sorenson, S. (2013). How Employee Engagement Drives Growth. Gallup Business Journal, 1, 1-4.

Thavakumar, D., \& Nawaratne, N. N. J. (2015). The Relationship between Training and Development Practices and Work Engagement in Sri Lankan Insurance Industry. International Journal of Research, 2, 615-627

Thisera, T. J. R., \& Nawaratne, N. N. J. (2018). Job Demands and Exposure to Workplace Bullying: A Study of State Universities in Sri Lanka. Asian Journal of Empirical Research, 8 , 195-207.

Thisera, T. J. R., \& Sewwandi, E. P. I. (2018). Transformational Leadership and Employee Engagement in Hospitality Sector in Sri Lanka. Global Journal of Management and Business Research, 18, 26-33.

Tuzun, I. K., \& Devrani, T. K. (2011). The Impact of Perceived Employee Identification 
on the Relationship between Customer Company-Identification and Customer Citizenship Behaviour: Practice from Turkish Hotels. African Journal of Business Management, 5, 1781-1786.

Wickramasinghe, V., \& Perera, S. (2014). Effects of Perceived Organisation Support, Employee Engagement and Organisation Citizenship Behaviour on Quality Performance. Total Quality Management \& Business Excellence, 25, 1280-1294. https://doi.org/10.1080/14783363.2012.728855

Xanthopoulou, D., Bakker, A. B., Demerouti, E., \& Schaufeli, W. B. (2007). The Role of Personal Resources in the Job Demands-Resources Model. International Journal of Stress Management, 14, 121-141. https://doi.org/10.1037/1072-5245.14.2.121

Xanthopoulou, D., Bakker, A. B., Demerouti, E., \& Schaufeli, W. B. (2009). Reciprocal Relationships between Job Resources, Personal Resources, and Work Engagement. Journal of Vocational Behavior, 74, 235-244. https://doi.org/10.1016/j.jvb.2008.11.003 